\title{
The Influence of the Internal Control System, Organizational Culture, Leadership Style, and Regional Financial Management System on the Implementation of Good Governance
}

\author{
Bambang Jatmiko ${ }^{1 *}$, Siska Nur Amalia ${ }^{2}$ \\ ${ }^{1,2}$ Department of Accounting, Faculty of Economic and Business, Universitas Muhammadiyah Yogyakarta, Indonesia \\ *Corresponding Author E-mail: bambang.jatmiko@umy.ac.id
}

\begin{abstract}
This study's purposes are to prove that the internal control system, organizational culture, leadership style, and the regional financial management system affects the implementation of good governance. The problem of this research is in the Ponorogo Regency, revealing that many corruption cases by government officials have not been resolved, and it has suffered tens of millions of losses. The objects were regional apparatus work units (SKPD) in the Ponorogo Regency. The sampling technique in this research was carried out utilizing purposive sampling with certain criteria applied. The results showed that the internal control system did not affect the implementation of good governance; organizational culture positively affected the implementation of good governance; leadership style positively affected the implementation of good governance; the regional financial management system positively affected the implementation of good governance.
\end{abstract}

Keywords: Internal Control Systems, Organizational Culture, Leadership Style, Regional Financial Management Systems, and Good Governance

\section{INTRODUCTION}

A good and clean government generally takes place in a society with effective social control, which is a characteristic of a democratic society where government power is limited and cannot act arbitrarily against citizens, including abuse of authority to commit acts of corruption, collusion, and nepotism. The realization and creation of a just, prosperous, and affluent society in general and the state management system requires the creation of good governance. The creation of good governance is applied to a state management system that is free from systems that tend to commit corruption, collusion, and nepotism.

Law Number 32 of 2004 concerning Regional Government and Law Number 25 of 2004 regulates the National Development Planning System. The main requirement in realizing the community's aspirations in achieving common goals and ideals is the implementation of good governance. Good governance can improve a climate of openness, participation, and accountability that aligns with the basic principles of good governance in the public sector (Prabawa et al., 2020). Basically, government organizations aim to provide good service to the community; here, government organizations are not to be served but to create conditions where people can develop their abilities and creativity to achieve common goals (Amalia, 2014).

The creation of good governance and a good state management system is needed to realize and create a good social order that does not re-implement a system with bad impacts: corruption, collusion, and nepotism (Wijaya et al., 2014). In addition, the crisis faced by the Indonesian people cannot be separated from the failure in developing the state administration system and not paying heed to the principles of good governance. The fact that is often seen in the implementation of good governance is that there is still much corruption, which causes economic problems to be hampered and increases the high unemployment rate in Indonesia. The economy in Indonesia has experienced a monetary crisis since 1997-1998, which was marked by a very drastic weakening of the rupiah exchange rate caused by internal and external factors (Dunga et al., 2014). The monetary crisis that occurred in Indonesia was also the cause of the weak implementation of good governance.

The phenomenon in this study is the weak application of good governance, such as the problem of high corruption, which will trigger the impediment of the economic process in Indonesia, especially in the Ponorogo Regency. The high level of corruption also reflects that the implementation of good governance is still far from expectations (Wijaya et al., 2014). This phenomenon is a small part of the problem, 
proving that creating a good government cannot be achieved since several things must be improved and become a special concern for the government.

Besides, some obstacles caused the non-realization of good governance in the government of Ponorogo Regency, including the corruption case by the deputy governor in the case of the Special Allocation Fund for education in 2012 and 2014, which the case has not been completed until now and the state has been harmed IDR 8.1 billion; the bribery case of stealth recruitment by the former head of the Ponorogo Land Transport Organization at the transportation service in 2011 amounted to IDR 100 million; cases of rice seed corruption in 2017 and cost the state IDR 1.3 billion; corruption cases in RSUD (regional public hospital) by the former Director of RSUD in 2016 and suffered a loss of IDR 3.5 billion; the case of corruption from APBDes (local government budget) by the village head in Ponorogo in 2019 and suffered a loss of IDR 523 million.

Seen and observed from the vision and mission of Ponorogo Regency for the implementation of good governance, there is still no readiness and nothing that leads to the potential that exists in Ponorogo Regency. The written vision and mission are only to fulfill the ritual rules of the regional head in the office. Many policies are also taken from mere routine. In the era of broad autonomy, it should be a golden opportunity to catch up in everything and achieve it with hard work from all parties driven by the government.

\section{LITERATURE REVIEW}

\subsection{Good Governance}

Good governance is a concept of good governance in implementing the use of political authority and power to manage resources to develop a solid and responsible society and effectively by making legal regulations and policies that refer to people's welfare, decision making, and implementation of policy management. Good governance includes all mechanisms, processes, and institutions through which citizens and community groups express their interests through legal rights, fulfill obligations and bridge differences between the two parties.

In order for good governance to run well, cooperation between all parties is needed, both from the government, private sector, and the community, for the achievement of effective and efficient good governance, interpretation, equality, as well as a high work ethic and morals that are firmly held by all components directly related to good governance. These three institutions are the main supporters of the creation of good governance. A good governance system will be realized if there is a synergy between the government, the private sector, and the community in realizing sustainable development. The state must also be able to create conducive conditions for the implementation of good governance.

\subsection{Internal Control System}

The internal control system is a set of policies and regulations to supervise, direct, and protect resources to avoid all forms of abuse and misappropriation. The internal control system monitors operational activities running in accordance with established policies and regulations.

Hery (2004) concluded that the purposes of the internal control system are to provide adequate assurance that:

1. Assets owned by the company have been properly secured and will only be used for the company's benefit, not for the interests of certain individuals or employees. An internal control system is implemented so that all assets owned by the company will be protected from acts of fraud, theft, or misuse that are not in accordance with interests.

2. Accounting information on the company is available on an accrual basis and can be relied on. It is done by minimizing the risk of intentional or unintentional misstatement of financial statements.

\section{Employees obey laws and regulations.}

\subsection{Organizational Culture}

Organizational culture is a pattern/system in the form of attitudes, values, behavioral norms, beliefs, language, and rituals, which are formed, developed, and passed on to all organization members as the organization's personality that will distinguish it from other organizations. Also, it will determine how the group feels, think, and react in a diverse environment that serves to overcome the problem of adaptation to both internal and external.

According to Suwarto and Koeshartono (2010), the functions of organizational culture are:

1. Culture has a limitless role, creating a clear distinction between one organization and another.

2. Culture brings a sense of identity to organizational members.

3. Culture facilitates the emergence of commitment to something broader than the person.

4. Culture can increase the stability of the social system. Culture is also a social glue that helps unite the organization with appropriate standards of what employees should do or say.

5. Culture has a function as a meaning-making and control mechanism that will guide and shape the attitudes and behavior of employees.

\subsection{Leadership Style}

Leadership comes from the word "lead," which means to guide. Leadership is also the process of a person or group trying to influence the tasks and attitudes of others on a result to be achieved in the vision and mission of the organization. 
Moreover, leadership style is the ability of a leader to direct, influence, encourage and control people and their subordinates to do some work, consciously and voluntarily, in achieving a certain goal.

According to Suwanto (2011), the various leadership styles are as follows:

1. Directive leadership style. This leadership style allows subordinates to know what the leader expects of them, schedules work, and provides specific guidance on completing tasks.

2. Supportive leadership style. This leadership style is friendly and shows concern for the needs of subordinates.

3. Participative leadership style. This leadership style consults with subordinates and uses their advice before making a decision.

4. Achievement-oriented leadership style. This leadership style sets challenging goals and expects subordinates to perform at their highest level.

\subsection{Regional Financial Management System}

Regional financial management is all regional rights and obligations in the administration of regional government, which are assessed in all activities of planning, implementation, administration, reporting, accountability, and supervision of regional finances. Besides, goods can be used as regional assets as long as other regions or other parties have not controlled them in accordance with provisions or regulations. Government Regulation Number 71 of 2010 states eight principles of accounting and financial reporting: historical value, realization, accounting basis, substance over formal form, consistency, periodicity, fair presentation, and complete disclosure. The regional management system often heard is the integrity of the activities of planning, budgeting, implementation, administration, reporting, accountability, and supervision of regional finances.

Implementation in government is the impact of the government system, one of which is reporting financial statements as a form of accountability, which will later be examined by the Audit Board of the Republic of Indonesia (BPK) (Prabawa et al., 2020). Success in regional financial management directly impacts the success of regional autonomy; thus, efforts to realize good governance are getting bigger (Ristanti et al., 2014).

Meanwhile, the main factor of failure in realizing regional financial management is the abuse of authority. Violations that often occur are a form of weak ethics in regional financial management. In a situation like this, internal and external audits are needed to implement regional financial management. Misuse of regional finance can also cause enormous losses for the realization of common goals.

\section{RESEARCH METHOD}

The research object of this paper is Regional Apparatus Work Unit (SKPD) of Ponorogo Regency consists of agency, service, and office. The organizational structure in question is the head of the agency, the head of the department, the subdistrict head, and the secretariat. The data used was Quantitative data, using the population Regional Apparatus Work Unit (SKPD) of Ponorogo Regency. Meanwhile, The sampling technique in this study used the purposive sampling method with certain criteria determined and in accordance with the sample to be studied. The sampling technique is a way of determining the number of samples in accordance with the sample size that will be used as a data source by taking into account the characteristics and distribution of the population to obtain a representative sample. The data collection technique was carried out employing a survey method with primary data, namely a questionnaire. The type of scale used in this research questionnaire was the Linkert scale. The Linkert scale is used to measure attitudes, opinions, and views of a person or group of people regarding social phenomena. The respondents' answers were measured using the Linkert Scale with an assessment of 1 to 5. Then, the analysis of data is done using SPSS.

\section{DISCUSSION}

\subsection{Research Results}

Data collection in this study was carried out by distributing questionnaires addressed to heads of agencies, heads of offices, sub-district heads, and secretariats in the SKPD of Ponorogo Regency. Based on 104 questionnaires distributed, 90 questionnaires were returned, while 14 were not returned.

Table 1. Validity Test Results

\begin{tabular}{|c|c|c|c|c|}
\hline Variable & Item & $\begin{array}{c}\text { Pearson } \\
\text { correlation }\end{array}$ & $\begin{array}{c}\text { Sig. } \\
\text { Value }\end{array}$ & Information \\
\hline \multirow{16}{*}{$\begin{array}{l}\text { Internal } \\
\text { Control } \\
\text { System }\end{array}$} & SPI 1 & .510 & .000 & \multirow{16}{*}{ Valid } \\
\hline & SPI 2 & .564 & .000 & \\
\hline & SPI 3 & .607 & .000 & \\
\hline & SPI 4 & .624 & .000 & \\
\hline & SPI 5 & .452 & .000 & \\
\hline & SPI 6 & .294 & .005 & \\
\hline & SPI 7 & .659 & .000 & \\
\hline & SPI 8 & .275 & .009 & \\
\hline & SPI 9 & .601 & .000 & \\
\hline & SPI 10 & .543 & .000 & \\
\hline & SPI 11 & .620 & .000 & \\
\hline & SPI 12 & .475 & .000 & \\
\hline & SPI 13 & .563 & .000 & \\
\hline & SPI 14 & .311 & .003 & \\
\hline & SPI 15 & .688 & .000 & \\
\hline & SPI 16 & .318 & .002 & \\
\hline
\end{tabular}




\begin{tabular}{|c|c|c|c|c|}
\hline Variable & Item & $\begin{array}{c}\text { Pearson } \\
\text { correlation }\end{array}$ & $\begin{array}{c}\text { Sig. } \\
\text { Value }\end{array}$ & Information \\
\hline & SPI 17 & .558 & .000 & \\
\hline & SPI 18 & .630 & .000 & \\
\hline & SPI 19 & .676 & .000 & \\
\hline & SPI 20 & .224 & .034 & \\
\hline \multirow{12}{*}{$\begin{array}{l}\text { Organizational } \\
\text { Culture }\end{array}$} & BO 1 & .471 & .000 & \multirow{12}{*}{ Valid } \\
\hline & BO 2 & .496 & .000 & \\
\hline & BO 3 & .533 & .000 & \\
\hline & BO 4 & .591 & .000 & \\
\hline & BO 5 & .581 & .000 & \\
\hline & BO 6 & .480 & .000 & \\
\hline & BO 7 & .334 & .001 & \\
\hline & BO 8 & .416 & .000 & \\
\hline & BO 9 & .314 & .003 & \\
\hline & BO 10 & .396 & .000 & \\
\hline & BO 11 & .613 & .000 & \\
\hline & BO 12 & .500 & .000 & \\
\hline \multirow{16}{*}{$\begin{array}{l}\text { Leadership } \\
\text { Style }\end{array}$} & GK 1 & .543 & .000 & \multirow{16}{*}{ Valid } \\
\hline & GK 2 & .772 & .000 & \\
\hline & GK 3 & .690 & .000 & \\
\hline & GK 4 & .543 & .000 & \\
\hline & GK 5 & .576 & .000 & \\
\hline & GK 6 & .722 & .000 & \\
\hline & GK 7 & .632 & .000 & \\
\hline & GK 8 & .418 & .000 & \\
\hline & GK 9 & .613 & .000 & \\
\hline & GK 10 & .718 & .000 & \\
\hline & GK 11 & .767 & .000 & \\
\hline & GK 12 & .382 & .000 & \\
\hline & GK 13 & .560 & .000 & \\
\hline & GK 14 & .558 & .000 & \\
\hline & GK 15 & .626 & .000 & \\
\hline & GK 16 & .262 & .013 & \\
\hline \multirow{11}{*}{$\begin{array}{l}\text { Regional } \\
\text { Financial } \\
\text { Management } \\
\text { System }\end{array}$} & $\begin{array}{l}\text { SPKD } \\
1\end{array}$ & .729 & .000 & \multirow{11}{*}{ Valid } \\
\hline & $\begin{array}{l}\text { SPKD } \\
2\end{array}$ & .749 & .000 & \\
\hline & $\begin{array}{l}\text { SPKD } \\
3\end{array}$ & .574 & .000 & \\
\hline & $\begin{array}{l}\text { SPKD } \\
4\end{array}$ & .743 & .000 & \\
\hline & $\begin{array}{l}\text { SPKD } \\
5\end{array}$ & .718 & .000 & \\
\hline & $\begin{array}{l}\text { SPKD } \\
6\end{array}$ & .612 & .000 & \\
\hline & $\begin{array}{l}\text { SPKD } \\
7 \\
\end{array}$ & .789 & .000 & \\
\hline & $\begin{array}{l}\text { SPKD } \\
8 \\
\end{array}$ & .679 & .000 & \\
\hline & $\begin{array}{l}\text { SPKD } \\
9\end{array}$ & .753 & .000 & \\
\hline & $\begin{array}{l}\text { SPKD } \\
10\end{array}$ & .648 & .000 & \\
\hline & $\begin{array}{l}\text { SPKD } \\
11\end{array}$ & .521 & .000 & \\
\hline
\end{tabular}

\begin{tabular}{|c|c|c|c|c|}
\hline Variable & Item & $\begin{array}{c}\text { Pearson } \\
\text { correlation }\end{array}$ & $\begin{array}{c}\text { Sig. } \\
\text { Value }\end{array}$ & Information \\
\hline & $\begin{array}{l}\text { SPKD } \\
12\end{array}$ & .587 & .000 & \\
\hline & $\begin{array}{l}\text { SPKD } \\
13\end{array}$ & .697 & .000 & \\
\hline & $\begin{array}{l}\text { SPKD } \\
14\end{array}$ & .734 & .000 & \\
\hline & $\begin{array}{l}\text { SPKD } \\
15\end{array}$ & .669 & .000 & \\
\hline & $\begin{array}{l}\text { SPKD } \\
16\end{array}$ & .573 & .000 & \\
\hline & $\begin{array}{l}\text { SPKD } \\
17\end{array}$ & .466 & .000 & \\
\hline & $\begin{array}{l}\text { SPKD } \\
18\end{array}$ & .593 & .000 & \\
\hline & $\begin{array}{l}\text { SPKD } \\
19\end{array}$ & .593 & .000 & \\
\hline & $\begin{array}{l}\text { SPKD } \\
20\end{array}$ & .432 & .000 & \\
\hline & $\begin{array}{l}\text { SPKD } \\
21\end{array}$ & .758 & .000 & \\
\hline & $\begin{array}{l}\text { SPKD } \\
22\end{array}$ & .782 & .000 & \\
\hline & $\begin{array}{l}\text { SPKD } \\
23\end{array}$ & .547 & .000 & \\
\hline \multirow{23}{*}{$\begin{array}{c}\text { Good } \\
\text { Governance } \\
\text { (GG) }\end{array}$} & GG 1 & .667 & .000 & \multirow{23}{*}{ Valid } \\
\hline & GG 2 & .531 & .000 & \\
\hline & GG 3 & .496 & .000 & \\
\hline & GG 4 & .422 & .000 & \\
\hline & GG 5 & .352 & .001 & \\
\hline & GG 6 & .582 & .000 & \\
\hline & GG 7 & .559 & .000 & \\
\hline & GG 8 & .441 & .000 & \\
\hline & GG 9 & .424 & .000 & \\
\hline & GG 10 & .783 & .000 & \\
\hline & GG 11 & .525 & .000 & \\
\hline & GG 12 & .531 & .000 & \\
\hline & GG 13 & .631 & .000 & \\
\hline & GG 14 & .561 & .000 & \\
\hline & GG 15 & .383 & .000 & \\
\hline & GG 16 & .721 & .000 & \\
\hline & GG 17 & .480 & .000 & \\
\hline & GG 18 & .782 & .000 & \\
\hline & GG 19 & .582 & .000 & \\
\hline & GG 20 & .648 & .000 & \\
\hline & GG 21 & .707 & .000 & \\
\hline & GG 22 & .665 & .000 & \\
\hline & GG 23 & .642 & .000 & \\
\hline
\end{tabular}

On Table 1, it can be seen that overall, the variables of the internal control system, organizational culture, leadership style, regional financial management system, and good governance had a value of r-count $>$ r-table. Besides, each item in the questionnaire had a sig. value of $<0.05$. Thus, it can be concluded that all statement items were valid and suitable to be used as measuring tools. 
A normality test was used to determine whether the data used in this study were normally distributed. Normality test was performed using the Kolmogorov Smirnov test. The data is said to be normally distributed if the Asymp Sig 2tailed value $>$ the level of significance $(\alpha=0.05)$ (Nazaruddin and Basuki, 2017).

Table 2. Normality Test

\begin{tabular}{|l|l|l|}
\hline Kolmogorov Smirnov & $\begin{array}{l}\text { Sig. } \\
\text { Value }\end{array}$ & Information \\
\hline $\begin{array}{l}\text { Unstandardized } \\
\text { Residual }\end{array}$ & 0.059 & $\begin{array}{l}\text { Normal } \\
\text { distribution }\end{array}$ \\
\hline
\end{tabular}

Based on the data in Table 2, the significance value for the Kolmogorov Smirnov test was 0.059. The value was higher than $5 \%$. Therefore, it can be denoted that the residuals were normally distributed, and the research data could be used for statistical testing at a later stage.

Moreover, the heteroscedasticity test tests whether there is an inequality of variance in the regression model from the residuals of one observation to another observation. The Glejser test can then be used to determine whether there is heteroscedasticity by regressing the absolute value of the residual as the dependent variable with various independent variables. A regression model can be declared not experiencing heteroscedasticity if the analysis results show a sig> alpha value of 0.05 , applied to each variable in each equation. The normality test results can be seen in the following table:

Table 3. Heteroscedasticity Test

\begin{tabular}{|l|l|l|}
\hline Independent Variables & Sig. & Information \\
\hline Internal Control System & 0.186 & $\begin{array}{l}\text { Non- } \\
\text { Heteroscedasticity }\end{array}$ \\
\hline Organizational Culture & 0.053 & $\begin{array}{l}\text { Non- } \\
\text { Heteroscedasticity }\end{array}$ \\
\hline Leadership Style & 0.908 & $\begin{array}{l}\text { Non- } \\
\text { Heteroscedasticity }\end{array}$ \\
\hline $\begin{array}{l}\text { Regional Financial } \\
\text { Management System }\end{array}$ & 0.786 & $\begin{array}{l}\text { Non- } \\
\text { Heteroscedasticity }\end{array}$ \\
\hline
\end{tabular}

Table 3 displays that the overall significance value of the variables in this study was greater than 0.05 , so it can be inferred that the regression model equation met the nonheteroscedasticity assumption. It indicates no significant relationship of the entire independent variables to the absolute value of the residual in the regression model, so it can be said that the variance inequality from one observation residual to another was fixed, or the data were homogeneous.

Further, the multicollinearity test in this study used the provisions that if the VIF value is $<10$ and the tolerance value is $>0.1$, then there is no multicollinearity between the variables. The multicollinearity test results can be seen in the following table:

Table 4. Multicollinearity Test

\begin{tabular}{|l|l|l|l|}
\hline \multirow{2}{*}{$\begin{array}{l}\text { Independent } \\
\text { Variables }\end{array}$} & \multicolumn{2}{|l|}{$\begin{array}{l}\text { Collinearity } \\
\text { Statistic }\end{array}$} & Information \\
\cline { 2 - 4 } & Tolerance & VIF & \\
\hline $\begin{array}{l}\text { Internal } \\
\text { Control System }\end{array}$ & 0.350 & 2.859 & $\begin{array}{l}\text { Free of } \\
\text { multicollinearity } \\
\text { symptoms }\end{array}$ \\
\hline $\begin{array}{l}\text { Organizational } \\
\text { Culture }\end{array}$ & 0.511 & 1.959 & $\begin{array}{l}\text { Free of } \\
\text { multicollinearity } \\
\text { symptoms }\end{array}$ \\
\hline $\begin{array}{l}\text { Leadership } \\
\text { Style }\end{array}$ & 0.279 & 3.590 & $\begin{array}{l}\text { Free } \\
\text { multicollinearity } \\
\text { symptoms }\end{array}$ \\
\hline $\begin{array}{l}\text { Regional } \\
\text { Financial } \\
\text { Management } \\
\text { System }\end{array}$ & 0.247 & 4.045 & $\begin{array}{l}\text { Free } \\
\text { multicollinearity } \\
\text { symptoms }\end{array}$ \\
\hline
\end{tabular}

Based on Table 4 above, the tolerance value of all independent variables was above 0.1 , and the VIF value was below 10. Hence, it can be concluded that the regression model equation did not occur multicollinearity.

The regression model equation was then used to test whether the internal control system, organizational culture, leadership style, and regional financial management system positively affected good governance. Thus, a test was needed to determine the analytical model used and perform a coefficient of determination test (adjusted $\mathrm{R}$ square), simultaneous significance test $(\mathrm{F})$, and partial significance test $(\mathrm{t})$ based on existing provisions. Then, a multiple linear regression test was conducted to test the hypotheses in this study. This study had four independent variables: the Internal control system, organizational culture, leadership style, and regional financial management system, and one dependent variable: good governance. The multiple linear regression test itself is used to see the effect of several independent variables on the dependent variable. The results of multiple linear regression calculations can be seen in the following table:

Table 5. Multiple Regression Test

\begin{tabular}{|l|l|l|}
\hline \multirow{2}{*}{ Variable } & $\begin{array}{l}\text { Unstandardized } \\
\text { Coefficients }\end{array}$ & \multirow{2}{*}{ Sig. } \\
\cline { 2 - 2 } & \multicolumn{1}{|c|}{$\boldsymbol{\beta}$} & \\
\hline (Constant) & 0.232 & 0.960 \\
\hline $\begin{array}{l}\text { Internal Control } \\
\text { System }\end{array}$ & -0.111 & 0.169 \\
\hline Organizational Culture & 0.471 & 0.000 \\
\hline Leadership Style & 0.393 & 0.000 \\
\hline $\begin{array}{l}\text { Regional Financial } \\
\text { Management System }\end{array}$ & 0.561 & 0.000 \\
\hline
\end{tabular}




\subsection{DISCUSSION}

\subsubsection{Internal Control System on the Implementation of Good Governance}

The results of hypothesis testing for the internal control system variable obtained a significant value, namely $0.169>$ alpha 0.05 with a value of -0.111 . It means that the internal control system did not affect the implementation of good governance. Thus, $\mathrm{H} 1$ was rejected. It happened because of the lack of a superior role to his subordinates. In reality, internal control, which is part of risk management that every organization must carry out, was still inadequate.

\subsubsection{Organizational Culture on the Implementation of Good Governance}

The results of hypothesis testing for the organizational culture variable obtained a significance value, namely 0.000 $<$ alpha 0.05 with a value of 0.471 . It indicates that organizational culture had a positive effect on the implementation of good governance. The better the organizational culture, the better the organization's performance that can support the implementation of good governance since it is related to the life that goes on in the organization. Hence, H2 was accepted. With good organizational culture, a good attitude will be attached to employees. If employees in a government have behaved well, it will benefit the government because employees will work as much as possible without committing fraud and comply with applicable laws and regulations. If these conditions are realized, it will be easier for local governments to implement good governance.

\subsubsection{Leadership Style on the Implementation of Good Governance}

The results of hypothesis testing for the leadership style variable obtained a significance value, namely $0.000<$ alpha 0.05 with a value of 0.393 . It signifies that leadership style had a positive effect on the implementation of good governance. The better the organizational culture, the better the organization's performance that can support the implementation of good governance related to the life that goes on in the organization. Therefore, $\mathrm{H} 3$ was accepted. The better the leadership style carried out, the better the implementation of good governance. Leadership will be a milestone in the success of bureaucratic reform in public services towards the goal of good governance. Leaders are also expected to commit to implementing the principles of good governance, such as participation, transparency, and accountability in every work activity carried out.

Leadership style will affect the implementation of good governance. The leadership style will develop the leader's creativity in building a climate and carrying out his leadership functions to improve the organization.

\subsubsection{Regional Financial Management System on the Implementation of Good Governance}

The results of hypothesis testing for the regional financial management system variable obtained a significance value, namely $0.000<$ alpha 0.05 with a value of 0.561 . It denotes that the regional financial management system had a positive effect on the implementation of good governance. The implementation of good governance refers to a management system in accordance with the principles of democracy, where the government as a public servant has the duty to meet the community's needs in the implementation of disciplined financial system management, and regardless of interests that can harm the state. Thus, $\mathrm{H} 4$ was accepted.

The realization of the budget through the planning process should be carried out based on the best agreement for the common interest. Also, in the process, a mutual agreement is taken between the organization members. The implementation of regional financial management also uses the principle of justice, where the distribution of activity allocation funds is in accordance with the community's priority needs. In financial reporting, public sector organizations must present them in accordance with the principle of transparency.

\section{CONCLUSION}

This study aims to examine the effect of the internal control system, organizational culture, leadership style, and regional financial management system on the implementation of good governance. This research was conducted in the Regional Government Work Unit (SKPD) of Ponorogo Regency. Based on the results of testing, processing, and data analysis carried out, the following conclusions could be obtained:

1. Based on the results of testing the first hypothesis (H1), the internal control system did not affect the implementation of good governance; thus, $\mathrm{H} 1$ was rejected.

2. Based on the results of testing the second hypothesis $(\mathrm{H} 2)$, organizational culture positively affected the implementation of good governance; thus, $\mathrm{H} 2$ was accepted.

3. Based on the results of testing the third hypothesis (H3), leadership style positively affected the implementation of good governance; thus, H3 was accepted.

4. Based on the results of testing the fourth hypothesis $(\mathrm{H} 4)$, the regional financial management system positively affected the implementation of good governance; thus, $\mathrm{H} 4$ was accepted.

\section{REFERENCES}

[1] Amalia, 2014. (n.d.). Analisis Hubungan Antara Gaya Kepemimpinan, Disiplin Kerja, Pengawasan Kerja Dengan Kualitas Pelayanan (Gita Amalia). 77-99.

[2] Dunga, dkk, 2014. (2014). Penerapan prinsip good governance dalam tata kelola pemerintahan desa di kecamatan Telaga Jaya 
$\begin{array}{lcr}\text { kabupaten Gorontalo. } & \text { Applied } & \text { Microbiology and } \\ \text { Biotechnology, } & 85(1), & 2071-2079 .\end{array}$ https://doi.org/10.1016/j.bbapap.2013.06.007

[3] Hery. 2014. Akuntansi Dasar 1 dan 2. Jakarta: Kompas Gramedia

[4] Nazaruddin, Ietje., Agus Tri Basuki. (2017). Analisis Statistik Dengan SPSS. Yogyakarta, Danisa Media.

[5] Prabawa, S., Karamoy, H., \& Mawikere, L. (2020). Pengaruh Sistem Pengendalian Intern Dan Akuntabilitas Pengelolaan Keuangan Daerah Terhadap Good Governance (Studi Empiris Di Kabupaten Minahasa). Going Concern: Jurnal Riset Akuntansi, 15(2), 269. https://doi.org/10.32400/gc.15.2.28232.2020

[6] Ristanti, N. M. A., Sinarwati, N. K., \& Sujana, E. (2014). Pengaruh Sistem Pengendalian Intern, Pengelolaan Keuangan Daerah Dan Komitmen Organisasi Terhadap Penerapan Good Governance. Jurnal Akuntansi, 2(1), 1-11.

[7] Suwanto. 2011. Manajemen Sumber Daya Manusia dalam Organisasi Publik dan Bisnis. Alfabeta. Bandung

[8] Suwarto, F.X., Koeshartono, D., 2009, Budaya Organisasi: Kajian Konsep dan Implementasi, Penerbit Universitas Atma Jaya Yogyakarta, Yogyakarta.

[9] Wijaya. (2014). Pengaruh Implementasi Pengendalian Intern , Budaya Organisasi dan Total Quality Management Terhadap Penerapan Good Governance pada Dinas Pendapatan Daerah Kabupaten Buleleng e-Journal S1 Ak Universitas Pendidikan Ganesha. Jurnal Akuntansi, 2(1), 1-12. 